\title{
Питання психології
}

УДК 159. 923

DOI: $10.33099 / 2617-6858-20-54-1-210-214$

Шинкар М. І., аспірантка Інституту права, психології та інновачійної освіти Національного

університету Львівська політехніка

\section{ПРОБЛЕМА АСЕРТИВНОСТІ В СУЧАСНОМУ СУСПЛЬСТВІ}

Стаття присвячена розгляду сутності та психологічних особливостей феномена асертивності. 3'ясовано ідею асертивності як практичної методологічної теорії міжособистісної взаємодії. Наведено принципи та критерії асертивної поведінки. Розглянуто проблему асертивності в сучасному суспільстві.

Ключові слова: асертивність; асертивна поведінка; впевненість у собі; міжособистісна взаємодія; принципи асертивності; спілкування.

Постановка проблеми. Соціальноекономічні та політичні процеси, що відбуваються в останні десятиліття в Україні привели до переосмислення значущості багатьох як індивідуальних, так і суспільних цінностей, зміни соціальних стереотипів та міжособистісної взаємодії. Асертивність як готовність особистості відстоювати власну позицію, навіть у тих випадках, коли вона суперечить позиції більшості, наразі набуває особливого значення в соціумі зі значним арсеналом засобів тиску, маніпуляцій i підкорення волі індивіда. Зважаючи на це, готовність та вміння відстоювати власну позицію й діяти незалежно від думки більшості можуть бути доленосними, як для окремої людини, так і суспільства загалом. Отже, проблема асертивності, асертивної поведінки в сучасному суспільстві стає особливо актуальною як у соціальному, так i в наукових аспектах.

Аналіз останніх досліджень i публікацій. Проблема асертивності привертала увагу вчених 3 кінця XIX століття. Її вивченням займались А. Адлер, Р. Альберті, Э. Берн, П. Ванцвайг, В. Вендланд, Дж. Вольпе, У. Джеймс, Ф. Зимбардо, А. Лазарус, А. Сальтер, Дж. Смит, Р. і Р. Ульрихи, Э. Шостром, М. Еммонс та інші. У кінці 50-х - на початку 60-х років у працях американського психолога А. Солтера сформувалась концепція асертивності, яка увібрала в себе основні положення гуманістичної психології та трансактного аналізу. У лексиконі східноєвропейськихпсихологів термін «асертивність» 3'явився після публікації книжки чеських авторів В. Каппоні та Т. Новака [3]. Під цим терміном у психологічній літературі стали розуміти певну особистісну автономію, незалежність від зовнішніх впливів та оцінок, здатність самостійно регулювати свою поведінку та вміння конструктивно знаходити вихід 3 проблемних ситуацій у спілкуванні. Близьким до поняття асертивності $€$ поняття впевненості в собі, Більшість психологів ототожнюють ці поняття. На нашу думку, асертивність відображає, насамперед, зовнішні, поведінкові прояви, а впевненість у собі характеризується внутрішніми переживаннями стосовно відповідності самооцінки реальним можливостям. Якщо самооцінка вища за реальні можливості, то така людина буде самовпевненою, якщо самооцінка буде нижча за реальні можливості - невпевненою. С. Стаут наводить визначення асертивної особистості: «асертивна людина - та, що відповідає за власну поведінку, демонструє самоповагу і повагу до інших, позитивна, слухає, розуміє i намагається дійти до робочого компромісу». Основними складовими асертивності, на його думку, $є$ наявність самоповаги та поваги до інших, а також здатність прийняти на себе відповідальність за власну поведінку. За своєю суттю асертивність - це філософія особистісної відповідальності. Із впевненістю та асертивністю корелюють такі якості особистості як емоційна зрілість, висока самооцінка, гнучкість, низький рівень конфліктності. У вивченні проблеми асертивності ми опираємося на праці В. Каппоні, Т. Новака, М. Джеймса, Д. Джонгварда, М. Мольца, Г. Бейера, Е. Алберті, М. Еммонса та інших, які присвячені опису поведінкової моделі успішної людини. Спираючись на роботи А. Сальтера, В. Каппоні, Т. Новак, С. Бішоп, 


\section{Питання психології}

уточнено поняття асертивності як гармонійного об'єднання властивостей особистості, що виявляється у природній, чесній поведінці по відношенню до себе та оточуючих людей, уміннях i навичках етично допустимого спілкування в конкретній ситуації при поєднанні 3 упевненістю, позитивною самооцінкою й за обов'язкової поваги до прав інших людей. У сучасних довідкових психологічних джерелах можна знайти визначення терміна «асертивність» як здатності людини впевнено і 3 гідністю відстоювати свої права, не принижувати при цьому прав інших [1]. Асертивність як один із факторів емоційного інтелекту вивчали М. Баркер, Р. Елберт і М. Еммонс, М. Сміт, В. Ромек, С. Нікітін, Н. Харламенкова, Є. Андрієнко. Асертивність - це самоствердження через конструктивну діяльність, досягнення майстерності безконфліктного спілкування. Всі автори сходяться на тому, що асертивна поведінка $\epsilon$ «золотою серединою» між агресивним та пасивним стилями поведінки. Асертивна поведінка спрямована на те, щоб реалізація власних інтересів була умовою реалізації інтересів суб'єктів взаємодії. У лексиконі східноєвропейських психологів термін «асертивність» з'явився після публікації книжки чеських авторів В. Каппоні та Т. Новака. Під цим терміном у психологічній літературі стали розуміти певну особистісну автономію, незалежність від зовнішніх впливів та оцінок, здатність самостійно регулювати свою поведінку та вміння конструктивно знаходити вихід 3 проблемних ситуацій у спілкуванні. $\mathrm{y}$ працях К. Абульханової-Славської, Г. Абрамової, I. Кона, В. Слободчикова, Є. Ісаєва, Л. Когана, О. Хухлаева, С. Гапонової, А. Созонтова, Н. Сабліної, В. Секун, А. Темніцкого, В. Лісовського феномен та ін розглядаються питання психологічного зростання особистості в період студентства. Здатність до конструктивної взаємодії 3 іншими людьми, розуміння i визнання цінності іншої людини, становлення авторства власного життя, прагнення до продуктивності життя - дозволяе нам говорити про можливість формування асертивності у студентів вузу. У сучасній психологічній науці досліджується вплив асертивності на досягнення успіху в діяльності (І. Зінов'єва, О. Нікітіна, М. Сміт та інші); впевненість вивчається як соціально-психологічна характеристика особистості (I. Ромек, Є. Смаглій); розробляються психотерапевтичні методики, зміст i форми соціальнопсихологічного навчання, які підвищують рівень самооцінки людини та іiі впевненість у своїх силах (К. Роджерс, Т. Яценко та інші).

Мета статті - висвітлити сутність та психологічні особливості феномена асертивності в сучасному суспільстві.

Методи дослідження: аналіз, узагальнення, систематизація наукових матеріалів, підпорядкованих завданню виявлення основних методологічних підходів та теоретико-емпіричного вивчення асертивності 3 метою концептуалізації даного феномену.

Виклад основного матеріалу.

Термін «асертивність» походить від англійського дієслова «to assert» наполягати на своєму, захищати свої права. Асертивна поведінка притаманна для людини, яка поважає себе та інших, незалежна від зовнішніх впливів та оцінок, здатна самостійно регулювати власну поведінку та відповідати за неї. Вона супроводжується наполегливістю та сміливістю, вмінням відкрито говорити про свої почуття і бажання. У світлі вищесказаного, дослідження асертивності на сучасному етапі розвитку суспільства представляє значний інтерес.

У психології асертивність розуміється як якість особистості, як здатність людини конструктивно відстоювати свої права, демонструвати позитивне i шанобливе ставлення до інших людей, як здатність захищати власні інтереси, формулювати i відстоювати свою думку, вільно висловлювати свої почуття i емоції, досягати поставленої мети, при цьому не порушувати права інших людей і брати на себе відповідальність за власну поведінку [3, $11,12]$.

Ідея асертивності як практична методологічна теорія міжособистісної взаємодії була запропонована й розроблена американським психологом А.Солтером. Асертивність (від лат. аззего претендувати; від англ. дієслова авзегі, наполягати, відстоювати) досліджувалась автором як певний спосіб поведінки особистості, що супроводжується почуттям поваги до власної індивідуальності та 


\section{Питання психології}

емоційно-ціннісним ставленням до інших людей.

А. Солтер вважає, що особистість із розвинутим почуттям самоповаги в будьякій ситуації спроможна діяти асертивно, тобто відкрито, впевнено й рішуче. Асертивні дії особистості розкриваються в такій поведінці, як: знання власних прав та обов'язків; адекватне оцінювання себе й оточуючих; усвідомлення особистих потреб та інтересів; розуміння власних цілей, намірів і шляхів подальших дій, при цьому здатність відкрито без страху й напруги про це заявляти; поважне ставлення до прав та інтересів інших людей; здатність досягати поставлених цілей, не маніпулюючи іншими; уміння переконувати, завойовувати прихильність, звертатися за порадою чи допомогою до людей; спроможність укладати компромісні рішення; встановлювати ділові контакти та партнерські відносини [7].

У працях чеських психологів В. Каппоні й Т. Новак асертивність розглядається як гармонійне поєднання особистісних якостей людини, що відображаються у формі конкретних світоглядних позицій та позитивній спрямованості, проявляються у знаннях про людську сутність, у вміннях і навичках ефективної взаємодії. Асертивність - це спосіб організації своєї поведінки, уміння формулювати особистісні потреби й бажання, прагнення до честолюбства у досягненні намічених цілей, шанобливе ставлення до людей, а головне - повага i любов до себе [3].

Так, В. А. Семиченко стверджує, що асертивність $€$ системоутворювальним ядром почугтя поваги та власної гідності. Вона розглядає асертивність як індивідуально-ціннісну якість, яка проявляється в активних діях особистості, зокрема у вмінні зберігати власну «автономність», уникаючи тиску та маніпуляції з боку оточуючих [5].

На думку американського психолога М. Дойча, особистість, яка поважає і цінує себе, вирізняється високим рівнем асертивної поведінки. Автор сформулював «троїстий принцип», який полягає в тому, що в будьякій ситуації асертивна особистість діє рішуче, чесно i дружелюбно. Психолог зазначає, що рішучість особистості не дозволить опонентові маніпулювати нею або залякати іï, чесність не дозволить бути втягнутому в аморальну ситуацію, навіть коли iї будуть провокувати на це, дружелюбність дасть зрозуміти опонентам, що така особистість поважає й цінує не тільки власну думку i тому готова до конструктивної взаємодії [2].

У соціально-психологічному словнику подано визначення асертивності, яка розглядається як якість особистості, як іiі риса, що виявляється в самоствердженні, свідомому прийнятті вимог інших людей без власного страху, невпевненості, напруги, iронії i т. ін. Таким особам властиві позитивне ставлення до людей і адекватна самооцінка [6].

Принципи асертивності - це емпіричні правила поведінки в суспільстві, спілкування 3 оточенням. Причому спілкування спирається на істинно гуманістичні основи, заперечується маніпуляція, жорстокість і агресія стосовно іншого. Можна сказати, що асертивність $€$ адекватною оцінкою свого стану й поведінки, це шлях до самореалізації, саморозвитку. У психології тлумачення цього терміна значно ширше. Поняття «асертивність» не існує само по собі, а включає достатньо широкий спектр суміжних понять, 3 якими має прямий $\mathrm{i}$ зворотній зв'язок. Прямий зв'язок складають такі поняття як: асертивна поведінка, впевнена поведінка, ефективна комунікація, емоційна та соціальна компетентність, соціальна сміливість. Зворотний зв'язок агресивна, пасивна поведінка, маніпуляція, невпевненість, соціальний страх, нерішучість та ін.

Заново набута поведінка буде проявлятися наступним чином. Люди, схильні до пасивного реагування, коригуючи свою пасивну поведінку з метою набуття асертивних поведінкових навичок, відкриють для себе, що все, що їм потрібно - бути сильнішими, перестати хвилюватися про те, що подумають інші, i не соромлячись говорити про свої бажання i потреби.

Невелика корекція пасивної поведінки дозволяе діяти активно - вирішувати проблеми, а не уникати їх. Впевненість надає сміливості і можливості відкрито висловлювати думки, які раніше не наважувалися озвучити, і навіть отримати те, про що мріяли. 


\section{Питання психології}

Людині, яка схильна до агресивних реакцій у взаємодії з оточенням, необхідно пом'якшити свою природну напористість. Корекція агресивної поведінки дозволяє їй впевнитися, що це полегшує шлях до досягнення мети, адже нова поведінка менше дратує оточуючих. Таким чином, набута асертивна поведінка дозволяє стримувати спонтанні агресивні реакції, що раніше викликали невдоволення та гнів у інших. Загальним критерієм в обох випадках можна вважати вимоги оточуючих. Пасивним людям слід менше задумуватися над бажаннями інших та більше уваги приділяти власним бажанням. Тим, хто схильний до агресивного типу поведінки, варто менше думати про себе і рахуватися 3 вимогами інших [4].

Таким чином, у певних ситуаціях людина може поводитися асертивно, агресивно або пасивно. Асертивна поведінка виключає пасивність i агресію. Пасивні люди дозволяють іншим приймати за них рішення, навіть якщо знають, що згодом вони будуть про це шкодувати, відчувають себе безпорадними і безправними. Агресивна людина порушує права інших, нав'язуючи їм свою волю, принижуючи їх i ображаючи. Агресивність виключає взаємну пошану, оскільки має на увазі задоволення потреб агресора за рахунок утрати самоповаги тими, на кого спрямована його агресія. Отже, агресивна поведінка викликає оборону i спричиняє у відповідь також агресивну поведінку; пасивна поведінка - це прийняття «чужих» умов без урахування власних потреб і бажань; і лише асертивна поведінка представляє собою взаємодію особистостей на основі поваги, що надає можливість досягти бажаного результату.

Висновки та перспективи подальших досліджень. Асертивність наразі набуває особливого значення в соціумі. Проблема асертивності в сучасному суспільстві стає особливо актуальною як в соціальному, так i в науковому аспектах. Асертивність $\epsilon$ важливою детермінантою становлення особистості та сприяе розкриттю іii психологічного потенціалу. Вона впливає на розвиток ефективної комунікації, активності, відповідальності, соціальної сміливості у висуванні та вирішенні нових цілей i завдань. У світлі вищесказаного, дослідження асертивності на сучасному етапі розвитку суспільства представляє значний інтерес i потребує подальших теоретичних i практичних наукових узагальнень.

\section{Список використаних джерел}

1. Галицький В.М., Мельник О.В., Синявский В.В. Соціально-психологічний словник / В.М. Галицкий, О.В. Мельник, В.В. Синявский. - К., 2004. - 250 с.

2. Дойч М. Разрешение конфликта (Конструктивные и деструктивные процессы) / Мортон Дойч // Социально-политический журнал. - 1997. - № 1. - С. 202-212.

3. Каппони В., Новак Т. Как делать все посвоему, или Ассертивность - в жизнь. - СПб.: Питер, 1995. - $186 \mathrm{c}$.

4. Кейт Кинан. Уверенность в себе. - М.: Изд. ЭКСМО, 2006.- 80 с.

5. Семиченко В. А. Психологія особистості. - К.: Видавець Ешке О.М., 2001. - 427 с.

6. Подоляк Н.М. Психологічні особливості асертивності [Текст] / Н. М. Подоляк // Наука і освіта: Науково-практичний журнал Південного наукового Центру АПН України. - 2010. - N 9. - С. 108-111.

7. Salter A. Conditioned reflex therapy. New York: Farrar, Straus \& Giroux, 1949.

\section{Reference}

1. Halyts'kyy, V.M., Mel'nyk, O.V., Synyavskyy,V.V. (2004). Sotsial'no-psykholohichnyy slovnyk. [Socio-psychological dictionary]. Kyiv. $-2004 .-250$.

2. Dojch M. Razreshenie konflikta (Konstruktivnye i destruktivnye processy) / Morton Dojch // Social'no-politicheskij zhurnal. - 1997. - № 1. - S. 202-212.

3. Kapponi V., Novak T. Kak delat' vse po-svoemu, ili Assertivnost' - v zhizn'. - SPb.: Piter, 1995. - $186 \mathrm{~s}$.

4. Kejt Kinan. Uverennost' v sebe. - M.: Izd. JeKSMO, 2006. - 80 s.

5. Semichenko V.A. Psihologija osobistosti. - K.: Vidavec' Eshke O.M., 2001. - 427 s.

6. Podoljak N.M. Psihologichni osoblivosti asertivnosti [Tekst] / N.M. Podoljak // Nauka i osvita: Naukovo-praktichnij zhurnal Pivdennogo naukovogo Centru APN Ukraïni. - 2010. - N 9. - S. 108-111.

7. Salter A. Conditioned reflex therapy. New York: Farrar, Straus \& Giroux, 1949. 


\section{Питання психології}

Резюме

Шинкар М. И., аспирантка Института права, психологии и инновационного образования

Наџионального университета Львовская политехника

\section{ПРОБЛЕМА АССЕРТИВНОСТИ В СОВРЕМЕННОМ ОБЩЕСТВЕ}

Статья посвящена рассмотрению сущности и психологических особенностей феномена ассертивности. Выяснено идею ассертивности как практической методологической теории межличностного взаимодействия. Приведены приниипь и критерии асертивнои поведения. Рассмотрена проблема ассертивности в современном обществе.

Ключевые слова: ассертивности; ассертивное поведение; уверенность в себе; межличностное взаимодействие; принцииь ассертивности; общения.

\section{Summary \\ Shynkar M. I., student of the Institute of Law, Psychology and Innovation Education of the National University Lviv Polytechnic \\ THE PROBLEM OF ASSERTIVENESS IN MODERN SOCIETY}

Introduction. The socio-economic and political processes that have taken place in recent decades in Ukraine have led to a rethinking of the importance of many, both individual and social values, changes in social stereotypes and interpersonal interaction. Assertiveness, as the willingness of the individual to assert his own position, even when it contradicts the position of the majority, is now of particular importance in a society with a considerable arsenal of means of pressure, manipulation and subjugation of the will of the individual. Against this background, the willingness and ability to defend one's position and act independently of the majority opinion can be fatal for both the individual and society as a whole. Thus, the problem of assertiveness, assertive behavior in modern society is becoming especially relevant in both social and scientific aspects.

Purpose. To clarify the essence and psychological features of the phenomenon of assertiveness in modern society.

Methods. Analysis, generalization, systematization of scientific materials, subordinated to the task of identifying the basic methodological approaches and theoretical and empirical study of assertiveness in order to conceptualize this phenomenon.

Originality. The article deals with the nature and psychological features of the phenomenon of assertiveness. The idea of assertiveness as a practical methodological theory of interpersonal interaction is clarified. The principles and criteria of assertive behavior are presented. The problem of assertiveness in modern society is considered.

Conclusion. Assertiveness is of particular importance in society. The problem of assertiveness in contemporary society is becoming especially relevant in both social and scientific aspects. Assertiveness is an important determinant of personality development and contributes to the disclosure of one's psychological potential. It influences the development of effective communication, activity, responsibility, social courage in advancing and meeting new goals and objectives. In the light of the above, the study of assertiveness at the present stage of society's development is of considerable interest and needs further theoretical and practical scientific generalizations.

Key words: assertiveness; assertive behavior; self-confidence; interpersonal interaction; principles of assertiveness; communication. 